Semmelweis Egyetem, Fogorvostudományi Kar, Orális Diagnosztikai Tanszék, Budapest*

Semmelweis Egyetem, Fogorvostudományi Kar, Fogpótlástani Klinika, Budapest**

Semmelweis Egyetem, Általános Orvostudományi Kar, Belgyógyászati és Hematológiai Klinika***

\title{
Életmentő korai diagnózis a fogorvosi székben Diffúz nagy B-sejtes lymphoma a sinus maxillarisban \\ Esetismertetés és irodalmi áttekintés
}

DR. MENSCH KÁROLY*, DR. SCHMIDT PÉTER ${ }^{\star *}$,

DR. FARKAS PÉTER ${ }^{\star * *}$, DR. KÁROLYHÁZY KATALIN**

\begin{abstract}
A non-Hodgkin lymphomák a fej-nyaki rosszindulatú daganatok ritka formái. Gyakran mellékleletként kerülnek diagnosztizálásra, vagy előrehaladott állapotban, a klinikai tünetek megjelenésével. A stomato-onkológiai szürés során akkor lehetséges diagnosztizálni, ha valamilyen mértékben a szájüreg felé kezd terjedni. Jelen közleményben egy sinus maxillarist érintő diffúz nagy B-sejtes lymphomás páciens diagnosztikai lépései, onkológiai ellátása és teljes fogászati rehabilitációja kerül bemutatásra, melyet nagymértékben meghatározott a páciens alapbetegsége. Végeredményben a korai diagnózisnak, az időben megkezdett sikeres onkológiai ellátásnak köszönhetően a daganat teljes remissziót mutatott, tizennyolc hónap elteltével relapszus nem jelentkezett. A páciens általános állapota jó, az elkészült fogászati restaurátumokkal, fogmúvekkel elégedett, rendszeres kontrollra visszajár.
\end{abstract}

Kulcsszavak: Non-Hodgkin lymphoma, sinus maxillaris, stomato-omkológiai szúrés, protetika

\section{Bevezetés, irodalmi áttekintés}

A lymphoproliferatív betegségek két nagyobb csoportba sorolhatók, úgymint Hodgkin-lymphoma $(\mathrm{HL})$ és nonHodgkin-lymphoma (NHL). A Hodgkin-lymphomák javarészt a nyirokcsomókat érintik, extranoduláris formái extrém ritkák. Kórszövettanilag a Reed-Sternberg sejtek (két-/többmagvú, bagolyszemszerủ sejtek) valamint a popcorn-szerú sejtmaggal rendelkező Hodgkin-sejtek jellemzik. Non-Hodgkin-lymphomák esetén mintegy 40\%-ban találkozunk extranoduláris formával. Érintheti a B-, T- vagy NK-sejteket, illetve kombinált proliferatív forma is elöfordul. A szájüregben a noduláris forma gyakoribb, ami a Waldeyer-féle gyürü (lingualis, palatinalis, pharyngealis tonsillák) területét érinti [4]. Szájüregben extrém ritka az extranoduláris forma, amennyiben megjelenik, akkor diffúz nagy B-sejtes lymphoma (DBCL) forma jellemző [3].

A non-Hodgkin lymphomák a fej-nyaki daganatok kevesebb, mint $1 \%$-át teszik ki. Jellemzően a nyirokcsomókat érintik, de ismertek extranoduláris formái is. Ezek közül a gastrointestinalis traktusban fordul elö leggyakrabban, ezt követően a paranasalis üregekben alakulhat ki elsősorban [3]. A sinus maxillarisban a laphámrákot követően a második leggyakoribb malignóma. Férfiaknál gyakoribb, jellemzően középkorúaknál és időseknél fordul elő. Az esetek mintegy kétharmadában a diffúz nagy B-sejtes lymphoma (DBCL) formájában jelenik meg. A sinusra lokalizált forma esetén ritkák a tünetek, azok csak előrehaladott állapotban jelennek meg: az orrüregbe, orbitába, szájüregbe betörhetnek, a csontos képletek destrukciójával és lágyszövetek involválásával járnak, orrüregi vérzést, elzáródást, deformitást okozva. Gyakori lehet még az exophtalmus, trismus, a kettős látás, fejfájás, illetve foglazulás [1].

Diagnosztikájára éppen a kései tünetek miatt általában elörehaladott állapotban kerül sor, szerencsés esetben véletlen melléklelet formájában, azonban korai diagnózis is előfordul. Diagnosztikáját segíti a mágneses rezonanciás vizsgálat (magnetic resonance imaging, $\mathrm{MRI}$ ), illetve a komputertomográfia (computed tomography, CT), a pontos diagnózishoz biopszia szükséges. Az orthopantomográf nem megbízható, mivel nincs jellemző röntgentünete [1].

A stomato-onkológiai szűrés minden új rendelésre érkezett páciensnél elvégzendő, illetve visszarendelt páciensek esetén legalább egyszer, évente, rizikópácienseknél (pl. erős dohányosok, szájüregi magas rizikójú humán papillomavírus (HPV)-fertőzéssel rendelkező páciensek esetén [7] gyakrabban. Ezen vizsgálat áll egy alapos anamnézis felvételéből, amely alapján stomato-onkológiai rizikó állapítható meg, illetve egy alapos extra-és intraorális vizsgálatból. Bizonyos esetekben - lásd az alábbiakban bemutatott pácienst is a lelkiismeretes és alapos szürővizsgálat ellenére is 
csak a páciens panaszaira és anamnézisére kell hagyatkozni, mivel a makroszkópos jelek nem utalnak feltétlenül szájüregi/fej-nyaki malignus folyamatra.

A fogorvosi ellátás során a megfelelő diagnózis alapján a kezelési terv felállításakor a szakmai irányelveket igyekszünk követni, betartani, azonban bizonyos esetekben a páciens általános állapota, esetleges alapbetegsége ezeket felülírhatja. Így kitüntetett szerepe lehet az individuális kezelési terv felállításának, az optimális kockázat/haszon arány mérlegelésével.

\section{Esetismertetés}

\section{Felvételi státusz}

51 éves férfi páciens, jó általános állapotban érkezett rendelésünkre. Foglalkozását tekintve kőmúves. A bal felső kvadránsban a premoláris fogai panaszosak, fogorvosa endodontiai ellátás céljából utalta be rendelésünkre, mivel a gyökércsatornák extrém mértékben szklerotizáltak voltak.

Általános anamnézisében a fogászati kezelést befolyásoló tényező nem szerepelt. Dohányzik, naponta 1 doboz cigarettát szív el. Extraorális vizsgálat során kismértékű aszimmetria volt észlelhető, temporomandibuláris ízületi diszfunkciót nem észleltünk, kóros nyirokcsomót nem tapintottunk.

Szájvizsgálat során a nyálkahártya épnek bizonyult, a stomato-onkológiai szürés negatív volt. Szájhigiéniája nem megfelelő. Szerzett mélyharapása volt. A támasztózónában érintkező fogak csak a bal oldali premoláris régióban voltak, a felső állcsonton bal oldalon hiányoztak a molárisai, elmondása szerint az utolsó bal felső moláris fogát 2016-ban veszítette el, az alsó állcsonton jobb oldalon hiányoztak a premoláris és moláris fogai, melyeket elmondása szerint több mint 10 éve veszített el. A foghiány a Fábián és Fejérdy protetikai osztályozás szerint a felső állcsonton 1/B osztályba, az alsó állcsonton 2/B osztályba tartozott (1., 2., 3. kép).

Parodontális státuszát tekintve szondázásra ínyvérzés volt megfigyelhető, mely a nem megfelelő szájhigiénia és a fogkő következménye volt. A bal alsó első moláris foga körül mesialisan $8 \mathrm{~mm}$ mély tasak volt szondázható (valójában mezializálódott második nagyőrlő, mely korábban traumás okklúzióban lehetett, és nehezen volt tisztítható), a fog mobilis volt.

A felső frontfogak palatinális felszínén, illetve az alsó frontfogak bukkális és incizális felszínén nagyfokú attríciót észleltünk. Több fogánál secunder caries, caries volt megfigyelhető, illetve több fognyaknál abrasio mutatkozott. Bal felső molárisok helyén fibrotikusan megvastagodott tuber maxillae képe látszott (4. kép).

A páciens elmondása szerint egy-két hete a bal felső kvadráns területén időnként nyilalló, erőteljes fájdalmat érzett, mely a napokban tompa, feszítő fájdalommá alakult. A klinikai vizsgálat során 24., 25. fogakban nagy kiterjedésú, MOD kompozit tömések voltak, secunder caries-szel. A nevezett fogak szenzibilitást nem mutat-

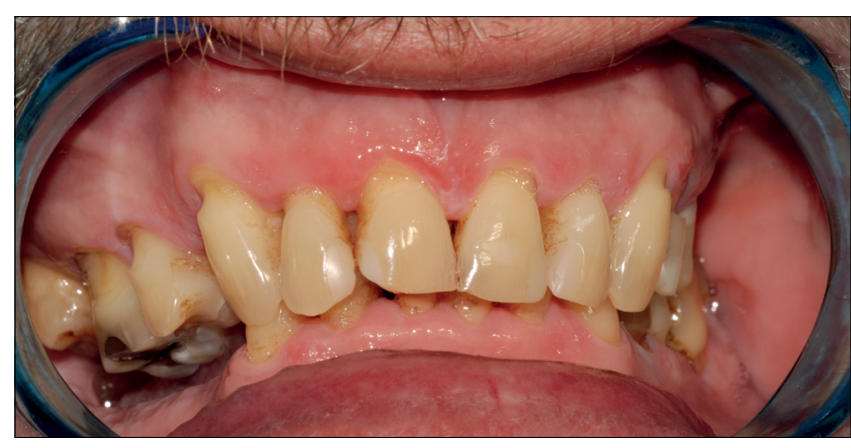

1. kép: Kiindulási állapot, IKP

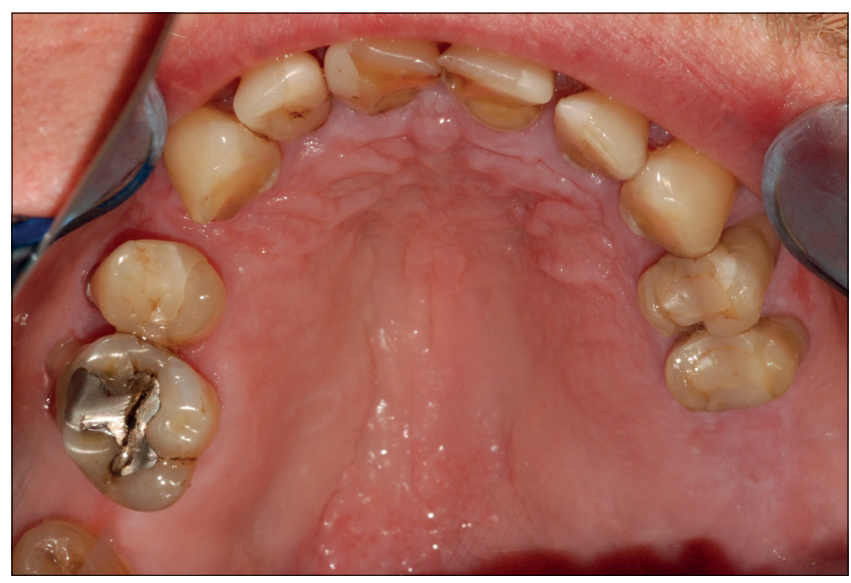

2. kép: Kiindulási állapot, felső állcsont

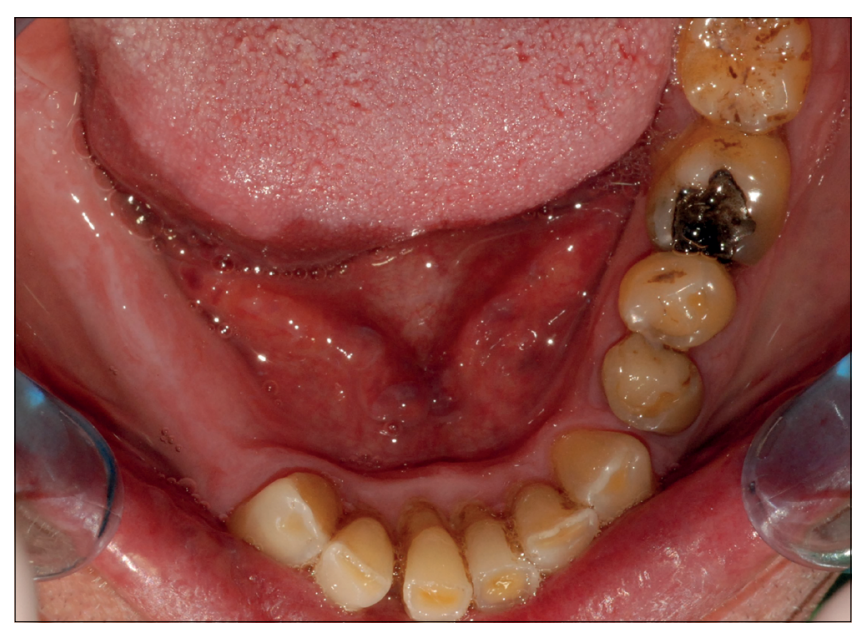

3. kép: Kiindulási állapot, alsó állcsont

tak, vertikális irányú kopogtatásra érzékenyek voltak, bal oldali arcduzzanat volt látható.

Intraorális röntgenfelvétel készült, melyen a 24. és 25. fogakban szklerotizált gyökércsatornák látszódtak, periapikális elváltozást nem láttunk. A páciens elmondása szerint a beutaló fogorvos megkísérelte a 24. fog endodontiai ellátását, azonban nem tudta feltárni a pulpakamrát a nagyfokú szklerotizáció miatt. (5. kép). A klinikai tünetek alapján a munkadiagnózis: a 24., 25. fog esetében periodontitis apicalis acuta. 


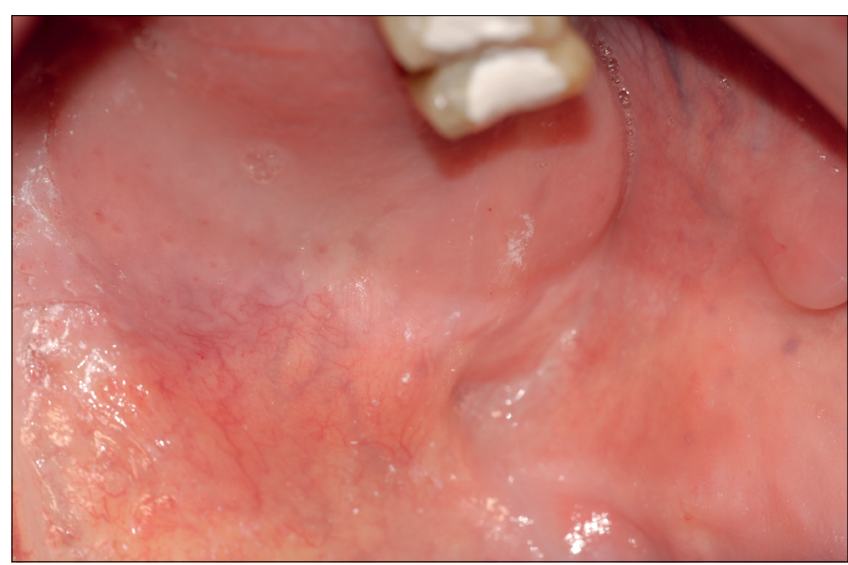

4. kép: Bal felső molárisok helyén lévő palatinális duzzanat

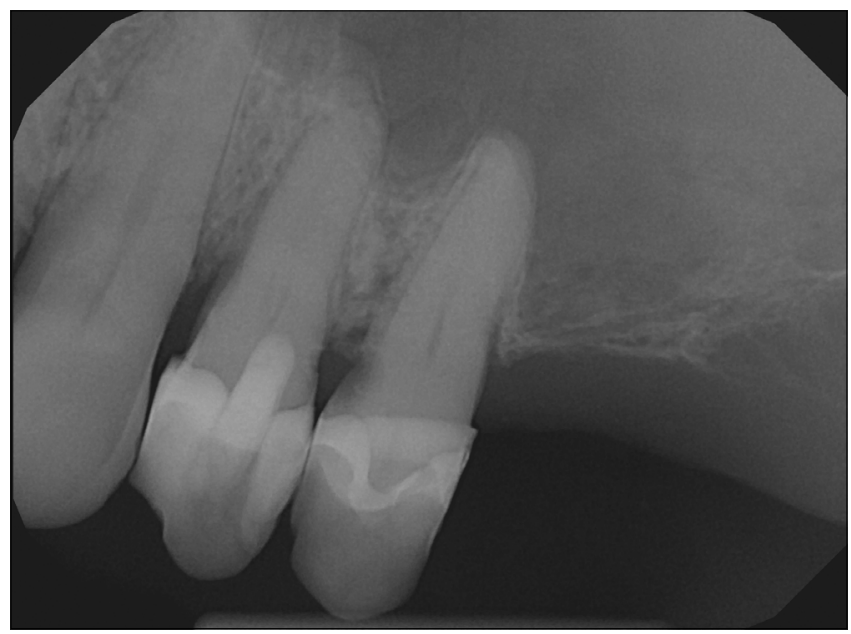

5. kép: Kiindulási intraorális röntgenfelvétel 24., 25. fogakról. 24. fogban elkezdett, majd félbehagyott trepanációs nyílás tömőanyaggal ellátva.

\section{A kezelés menete}

Kezelési terv: 24., 25. fog endodontiai ellátása. A sürgősségi ellátás keretében a 24. és 25 . fogak trepanálása megtörtént, a munkahossz apex lokátor és tüs röntgenkontroll-felvétel segítségével került meghatározásra. Kofferdam izolálást és step-back technikát alkalmaztunk a gyökércsatorna megmunkálásakor, a mesterfile \#25 méretű volt mindegyik csatorna esetében.

Apicalis stop kialakítása megtörtént. A 24. fog egy bukkális és egy palatinális gyökércsatornával rendelkezett, a 25. fog egy piskóta alakú gyökerében egy bukkális és egy palatinális csatorna volt fellelhető.

A gyökércsatornákat 2,5\%-os nátrium-hipoklorit oldattal öblítettük át, a mechanikai megmunkálást 17\%-os EDTA oldattal segítettük. A gyökércsatornák kiszárítását követően elkészítettük a gyökértömést, melyet laterál kondenzációs technikával végeztünk. Guttaperchát és AH Plus sealert (AH Plus, Dentsply DeTrey GmbH, Konstanz, Németország) alkalmaztunk. Az orifitiumokat fényre kötő üvegionomer cementtel zártuk le (Ionoseal, Voco GmbH, Cuxhaven, Németország), a koronai rész- be ideiglenes tömést helyeztünk (DC Temporaryfill, DC Dental Central GmbH, Hannover, Németország), a pácienst egy hét múlva rendeltük vissza definitív restaurátum elkészítése céljából. Kontroll röntgenfelvételt készítettünk, az elkészült gyökértömések megfelelőnek bizonyultak (6. kép).

A páciens egy hét elteltével elmondta, hogy panaszai nem javultak, ismételten éles, intenzív, késszúrásszerű fájdalmat érez, mely hosszabb-rövidebb ideig áll fenn, és random jelentkezik, illetve időnként intenzív bal oldali arczsibbadást érez.

A második klinikai vizsgálat során a következőket észleltük: a 24., 25. fogak kopogtatási érzékenysége csökkent. A molárisok területén palatinálisan a fogatlan gerinc élétől mintegy $1 \mathrm{~cm}$-re kb $1 \times 2 \mathrm{~cm}$ nagyságú fibrotikusnak tűnő terület volt megfigyelhető. Az elsődleges klinikai vizsgálat során a terület fibrotikusan megvastagodott tuber maxillae-nek imponált. A kiindulási periapikális röntgenfelvételen radix relicta nem ábrázolódott. $A$ nevezett területet alaposan megvizsgálva azt találtuk, hogy az palatinálisan gumiszerú tapintatú volt, enyhén nyomásra érzékeny. Orthopantomogramot kértünk (7. kép), melyen a bal felső moláris területen rendellenes morfológiát észleltünk. A panaszok figyelembevételével, illetve a klinikai és radiológiai vizsgálat alapján felmerült ameloblastoma, cemento-osseus dysplasia $[2,12]$, esetleges tumor gyanú, mely a bal oldali arcüreget érinti. Ennek tudatában sürgősséggel hisztológiai mintavétel céljából a területileg illetékes fekvő-

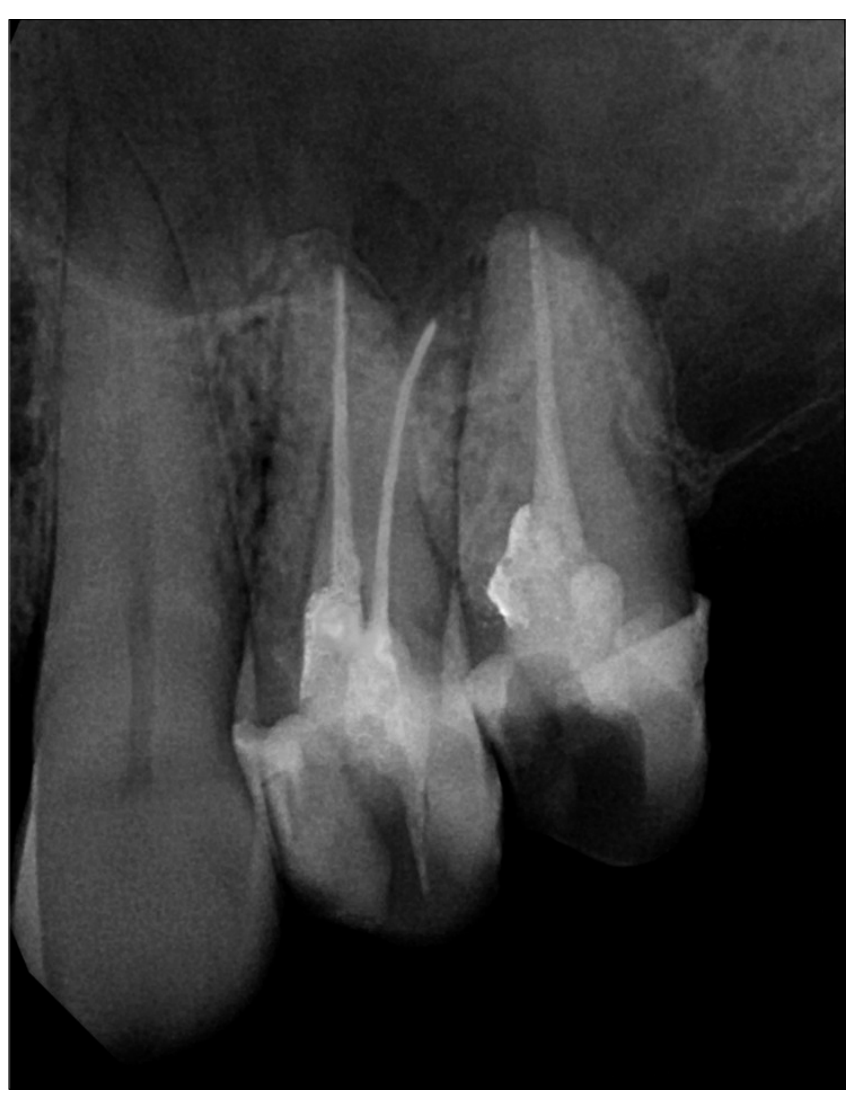

6. kép: Kontroll intraorális röntgenfelvétel a 24., 25. fogak endodontiai ellátását követően 


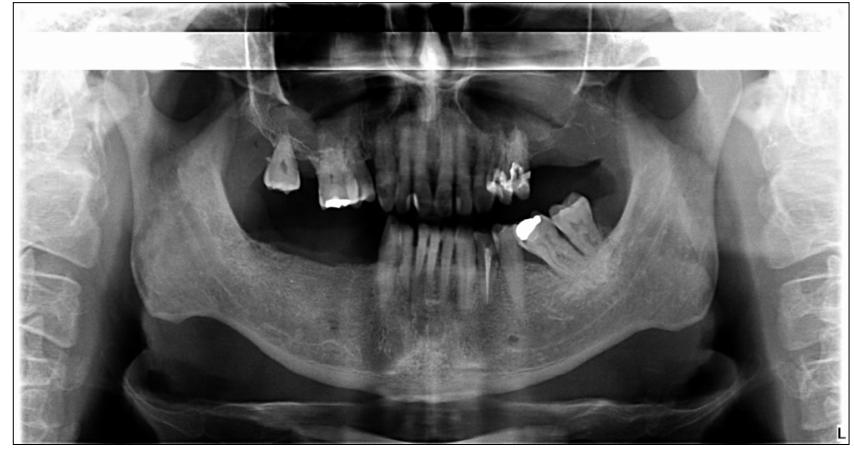

7. kép: Differenciáldiagnosztikai céllal készült orthopantomogram. A bal felső molárisok területén rendellenes morfológiát észleltünk, mely esetleges tumorgyanút vetett fel, ezért hisztológiai mintavétel és MR-felvétel készült.

osztályos szájsebészetre utaltuk a pácienst, illetve arckoponya MR-vizsgálatot kértünk. Az elkészült szövettani és MR-vizsgálat eredménye: bal oldali sinus maxillarist kitöltő diffúz nagy B-sejtes lymphoma.

A pácienst sürgősséggel haematológiai osztályra küldtük, ahol felvették őt. Pozitronemissziós tomográfiás (PET-CT) vizsgálat történt, mely a bal sinus maxillarist kitöltő, annak medialis és lateralis falát destruáló, a környező lágyrészekbe és a koponyabasis felé is terjedő térfoglaló folyamatot mutatott, viszont más lokalizációban rosszindulatú folyamatra utaló jel nem mutatkozott. A vizsgálatok alapján a diagnózis: I/A-E stádiumú high-grade B-sejtes lymphoma, ezért a páciens 4 sorozat rituximab-cyclophosphamid-doxorubicin-vincristin-methylprednisolon immunkemoterápiás kezelést kapott 21 naponként (R-CHOP21), a központi idegrendszerhez közeli lokalizáció miatt intrathecalis kemoprofilaxissal kiegészítve. A kezelés közbeni PET-CTvizsgálata komplett metabolikus remissziót mutatott, kezelését ezért még két sorozat immunkemoterápiával egészítették ki. 3 havonkénti haematológiai és MRkontrollja során eddig relapsus nem jelentkezett.

A páciens általános állapota kifejezetten jónak bizonyult a kezelés alatt, ezért 6 hónap elteltével a definitív fogászati ellátásának nem volt kontraindikációja.

Preprotetikai kezelés során supra- és subgingivális depurálás, kürettálás történt, illetve a páciens instruálására és motiválására is nagy hangsúlyt fektettünk [6]. A szájhigiénia javult. A klinikailag bal alsó első moláris fog valójában mesioangularis helyzetben lévő második moláris. A fog mobilis volt, mesialisan 7-8 mm tasakmélység volt szondázható, nagy kiterjedésú amalgám restaurátummal, illetve secunder caries-szel. A fogat a szervezet számára potenciális veszélyt jelentő gócnak ítéltük meg [5]. A leírtak miatt a fog eltávolítása mellett döntöttünk.

A frontfogak nyaki területén abrasio volt megfigyelhető, ezeket kompozit restaurátumokkal láttuk el. Jobb felső második premoláris fogban a kompozit restaurátum mellett secunder caries volt megfigyelhetö, illetve a jobb felső első moláris fogban lévő amalgám restaurátum mellett is. Ezen fogakat direkt kompozit restaurátummal láttuk el. A szanálást követően a foghiány a Fábián és Fejérdy protetikai osztályozás szerint a felső állcsonton 1/B, az alsó állcsonton 2/B osztályba tartozott.

A bal felső első és második premoláris fogak az endodontiai ellátást követően panaszmentesek voltak klinikailag és radiológiailag egyaránt. A hosszú távú ideiglenes restaurátumok eltávolítása után a klinikai korona mintegy kétharmada hiányzott, így csonkkiegészítés céljából öntött csapos múcsonkot terveztünk [13].

A protetikai kezelési terv a felső állcsonton 3 tagú distalisan szabad végű fémkerámia hídpótlás készítése volt. Leplezett horgonykoronák: bal felső első és második premoláris, leplezett hézagfog: bal felső első moláris, mely szabad vég. Jóllehet a szakmai irányelvek szerint nem javallott öntött csapos mücsonkkal ellátott pillérfogakra szabad végú hídpótlást tervezni [10], ez esetben azonban az alapbetegség miatt a fogatlan bal felső moláris terület maximális tiszteletben tartására kellett törekedni a rágóképesség minél hosszabb távú helyreállításakor, az esztétikai és funkcionális igények kielégítésével. Az alsó állcsontra a páciens szeretett volna implantátumon elhorgonyzott rögzített fogpótlást, azonban az alapbetegség miatt részleges lemezes fogpótlást terveztünk. A bal alsó első premoláris fog gyökérkezelt, nagy kiterjedésú kompozit töméssel, melyet fémkerámia borítókoronával terveztünk ellátni. A dentális megtámasztást a bal oldalon rágófelszíni támasztékkal, jobb oldalon a szemfogra kapocstartó fémkerámia koronán elhelyezkedő frézelt vállal biztosítottuk. A merev elhorgonyzás céljából öntött kapcsokat terveztünk.

A páciensnek szerzett mélyharapása volt, ezért a harapási magasság emelése szükséges volt. Kétfázisú egyidejü C-szilikon (Zetaplus és Oranwash, Zhermack GmbH, Marl Németország) szituációs lenyomatot vettünk kiinduláskor, melyre a fogtechnikai laboratóriumban (Interdental Studio) támasztócsapos regisztráló sablon készült. Ennek segítségével meghatároztuk a kívánatos harapási magasságot, a maxilla térbeli helyzetét arcív segítségével rögzítettük (8. kép). A beállított harapást harapásrögzítő szilikon (Colorbite $D$, Zhermack $\mathrm{GmbH}$, Marl, Németország) segítségével rögzí-

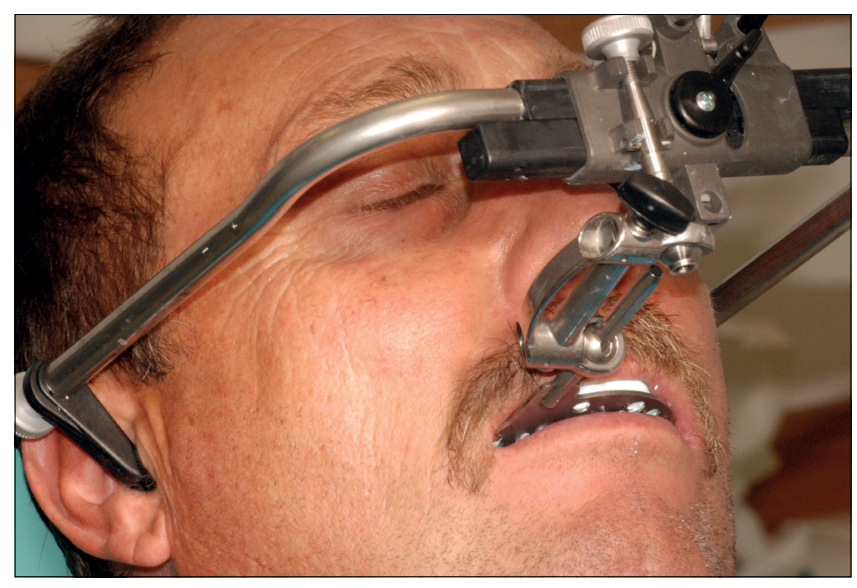

8. kép: Maxilla térbeli helyzetének rögzítése arcív segítségével 


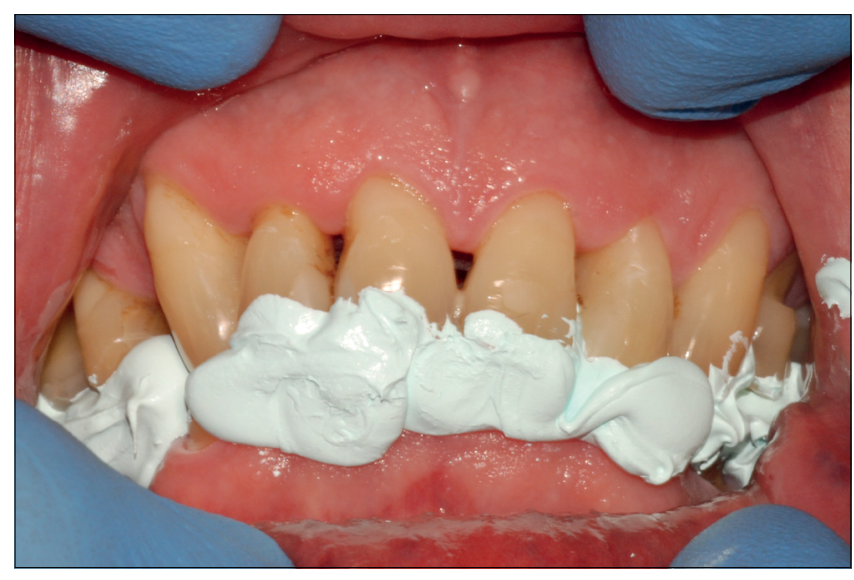

9. kép: Támasztócsapos regisztráló sablon segítségével beállított harapás rögzítése szilikon segítségével

tettük [8] (9. kép). Ennek megfelelően a mintákat részlegesen egyéni értékű artikulátorba (Kavo Protar 5B) gipszelték [9], majd a beállított harapási magasságnak megfelelően diagnosztikus felviaszolás (waxup) történt (10., 11., 12. kép). Ezáltal a beálított kívánatos harapási magasságot a frontfogak tartották. A felviaszolt mintáról átlátszó szilikon lenyomatanyaggal (Kristall A70 Perfect, Müller-Omicron $\mathrm{GmbH}$, Lindlar, Németország) sablont készítettünk, melynek segítségével direkt eljárással, kofferdam izolálásban, kompozit restauráció segítségével állítottuk helyre az attríciós frontfogakat (13. kép). Ezáltal elértük az előzetesen beállított, $4 \mathrm{~mm}$-rel megemelt kívánatos harapási magasságot (14. kép).

Következő ülésben a bal felső első és második premoláris fogak preparációja történt az öntött csapos mücsonkok készítéséhez, illetve a bal alsó első premoláris és jobb alsó szemfog preparációjára is sor került. Paragingivalis, legömbölyített vállas csonkelőkészítést végeztünk [13]. Ezen fogakra előzetes szilikon lenyomat alapján direkt technikával önkötő akrilát ideiglenes koronákat készítettünk. A preparálást követően kétfázisú egyidejú lenyomatot vettünk a felső állcsontról az öntött csapos múcsonkhoz és a fogtechnikai laboratórium által készített hosszú távú ideiglenes kéttagú sínhez, az alsó állcsontról pedig a laboratóriumi ideiglenes koronákhoz. A lenyomatokat C-típusú szilikon lenyomattal vettük (Zetaplus és Oranwash, Zhermack GmbH, Marl, Németország) két fázisban, külön időben.

A következő kezelés során az elkészült két öntött csapos múcsonk rögzítése megtörtént üvegionomer ragasztócement segítségével (15. kép) (Ketac Cem, 3M Germany GmbH, Neuss, Németország), illetve a hosszú távú ideiglenes restaurátumok rögzítésére is sor került (Tempbond NE, Kerr Italia S.r.l., Scafati, Olaszország). Ellenőriztük az artikulációt és okklúziót, a szükséges korrekciót elvégeztük.

A pácienst két hét múlva visszarendeltük. A megemelt harapási magasságot kényelmesnek találta, panaszmentes volt. İgy a definitív fogpótlás készítését elkezdtük. A preparált csonkokról kétfonalas sulcus tá- gítást alkalmazva, fém gyári lenyomatkanállal kétfázisú, külön idejü precíziós-szituációs lenyomatot vettünk A szilikon segítségével (Virtual Refill Putty és Virtual Refill Light Body, Ivoclar Vivadent AG, Schaan, Liechtenstein). Az interkuszpidációs pozíciót (IKP) harapásrögzítő szilikon segítségével rögzítettük két fázisban. Először az ideiglenes koronákat szájban hagyva rög-

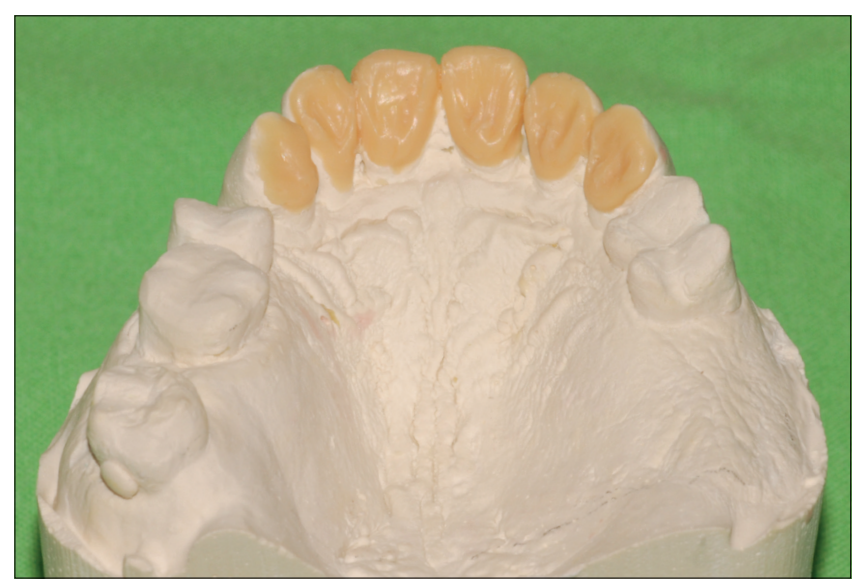

10. kép: Diagnosztikus felviaszolás (waxup) - felső állcsont

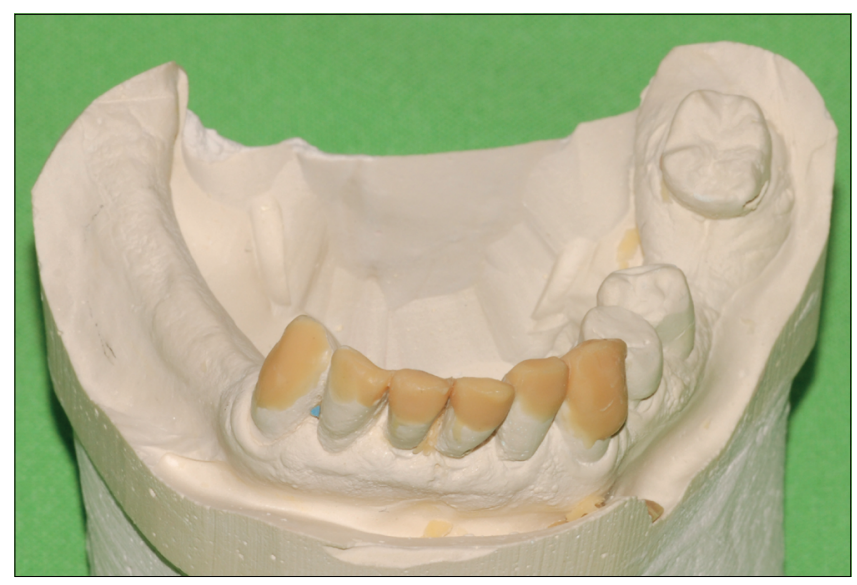

11. kép: Diagnosztikus felviaszolás (waxup) - alsó állcsont

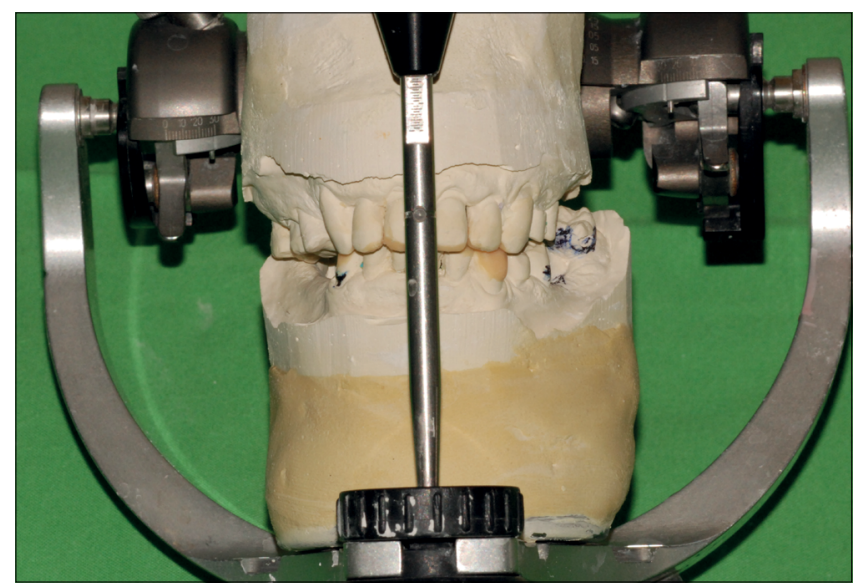

12. kép: Beállított harapási magasságnak megfelelően elkészített diagnosztikus felviaszolás (waxup) - artikulátorban 


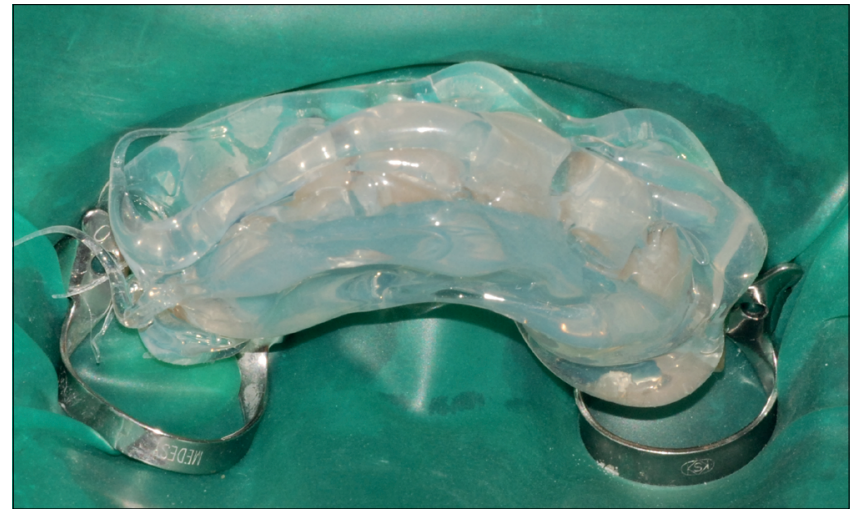

13. kép: Átlátszó szilikon átvivő sablon használata

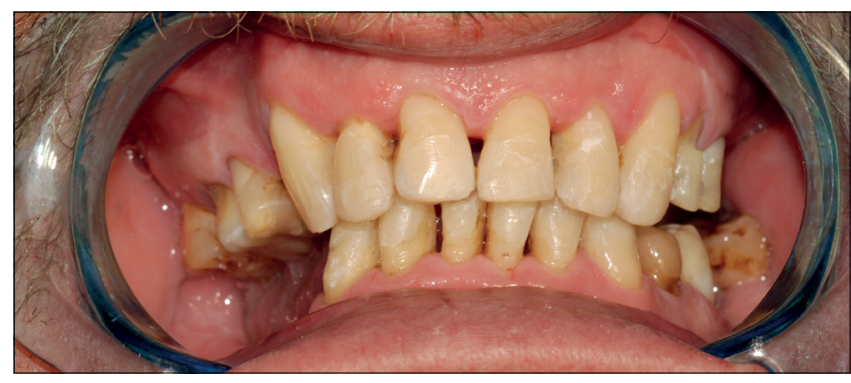

14. kép: Direkt eljárás segítségével kialakított, előzetesen meghatározott harapási magasságnak megfelelő IKP

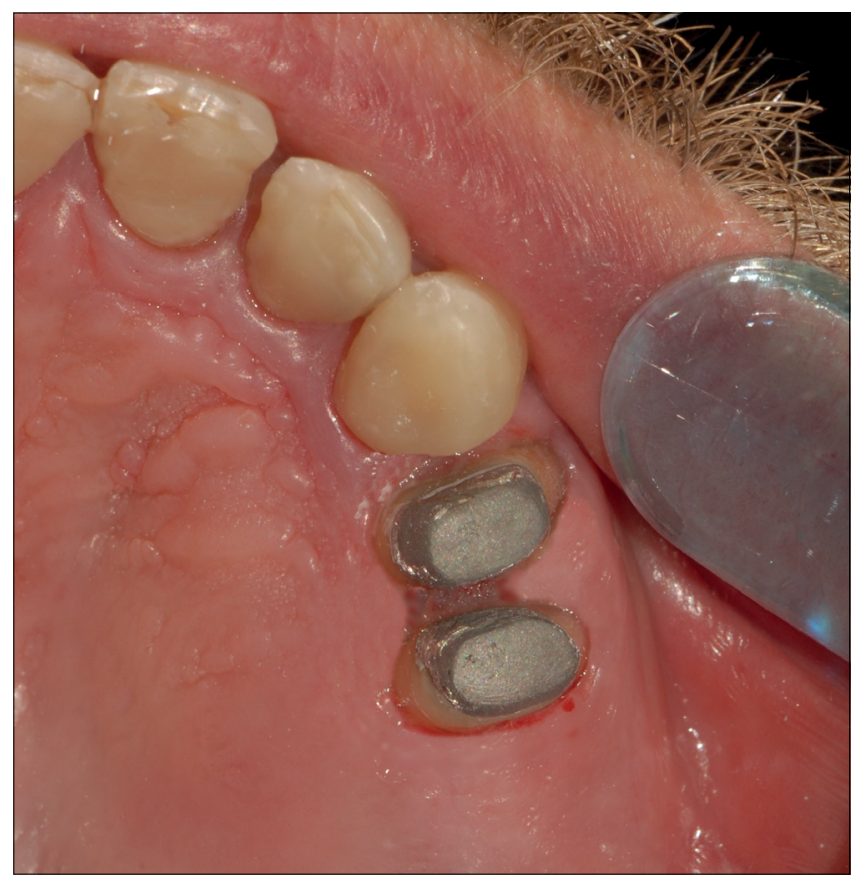

15. kép: Becementezett öntött csapos múcsonkok 24., 25. fogakban

zítettük az IKP-t, (ábrán zöld, Colorbite D, Zhermack GmbH, Marl, Németország), majd azokat eltávolítva az ideiglenes koronáknak megfelelő teret ismét feltöltöttük harapásrögzítő szilikonnal (ábrán magenta színű

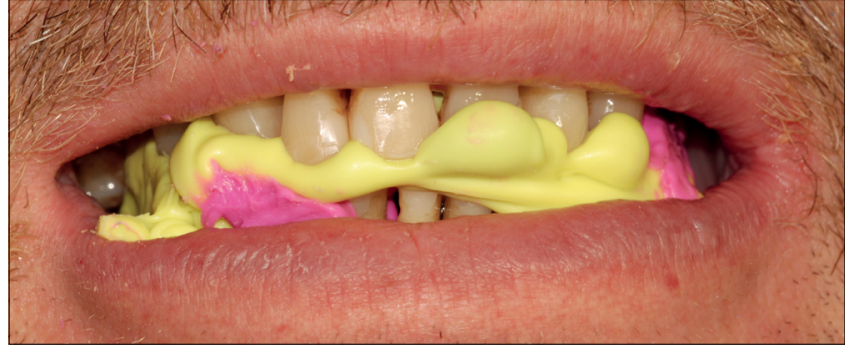

16. kép: IKP rögzítése harapásrögzítő szilikon segítségével, 2 fázisban

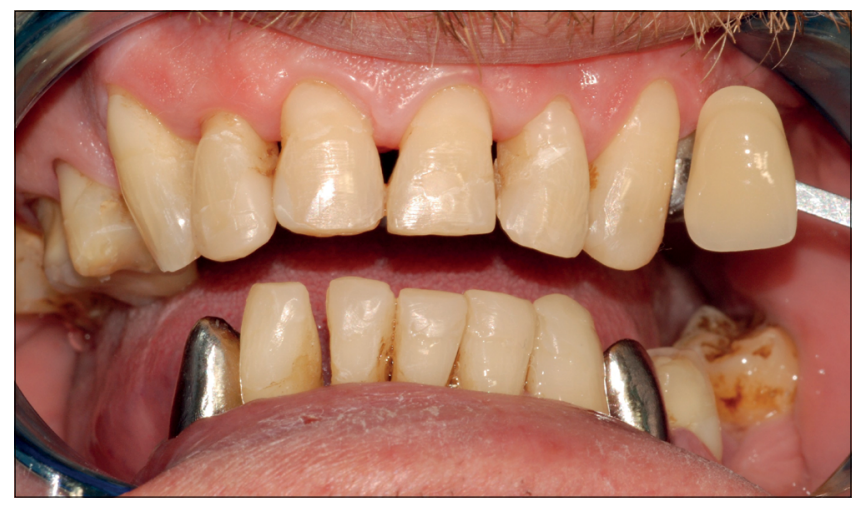

17. kép: Fémvázak ellenőrzése a szájban, fogszínválasztás. A fémvázakat megfelelőnek találtuk.

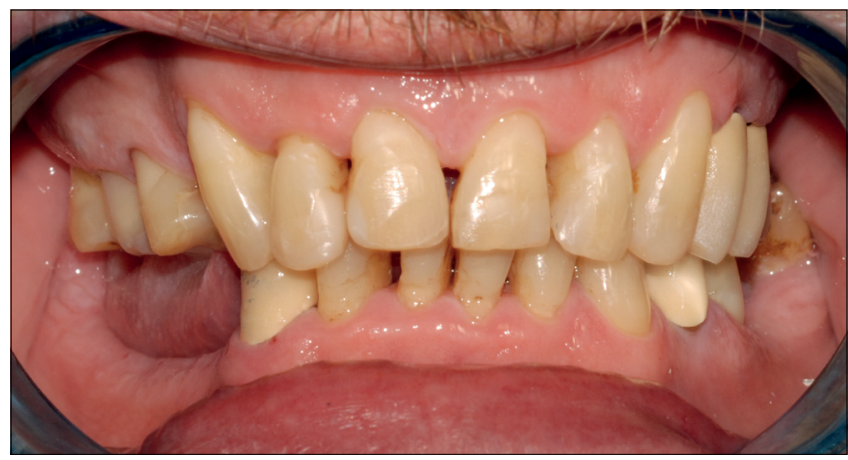

18. kép: Nyerspróba. Artikulációt, okklúziót ellenőriztük, az esztétikát megfelelőnek találtuk.

Futar D, Kettenbach GmbH \& Co. KG, Eschenburg, Németország) (16. kép).

A fogtechnikai laborban elkészítették a fémvázakat, melyeket az artikulátorban és a szájban ellenőriztünk (17. kép), azokat megfelelőnek találtuk. A fogszínt Vita Classical fogszínkulcs segítségével határoztuk meg, a fogszín A3,5. Következő ülésben a nyerspróba során ellenőriztük a fogszínt, a fogak formáját, az artikulációt és az okklúziót (18. kép), valamint az alsó állcsontról fényre kötő műanyag egyéni kanál segítségével közepes konzisztenciájú szilikon lenyomattal (Thixoflex M, Zhermack GmbH, Marl, Németország) szituációs lenyomatot vettünk a kombinált fogpótlás kivehető részéhez. A fogtechnikai laboratóriumban min- 


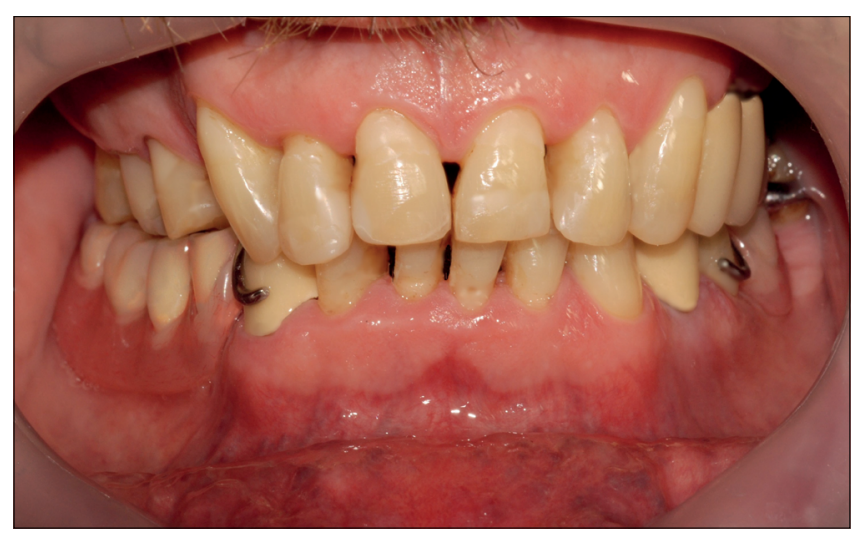

19. kép: Elkészült fogpótlások átadása. Az esztétikai és funkcionális szempontokat megfelelőnek találtuk.

tára öntési technikával elkészítették a fémlemezt viaszsáncokkal, mely segítségével rögzítettük az IKP-t. Ennek alapján elkészült a fogfelállítás. A próbafogsort ellenőriztük artikulátorban és szájban egyaránt. Megfelelőnek találtuk, így a laboratórium készre vitte a fogpótlásokat.

Ezután a fogpótlások definitív rögzítése megtörtént, üvegionomer ragasztócement segítségével (Ketac Cem, 3M Germany GmbH, Neuss, Németország). Az artikulációt és okklúziót ellenőriztük, a szükséges korrigálásokat elvégeztük (19. kép).

Rövid távú visszarendelés során a páciens szájhigiéniás instruálása, motiválása megtörtént. A páciens kezdeti szkepticizmusa a kivehető fogpótlás irányába a visszarendelés során elmúlt. A hosszú távú (1, 3, 6 hónapos) kontroll során tapasztaltuk, hogy a páciens az elkészült fogpótlást elégedetten viseli. A kivehető részt hosszú távú ideiglenes fogpótlásnak terveztük, azonban úgy ítéljük meg, hogy definitív fogpótlásként tud funkcionálni.

\section{Összefoglalás}

A diffúz nagy B-sejtes lymphoma ritkán jelentkezik a fejnyaki régióban, azonban a sinus maxillarist érintő rosszindulatú daganatok esetén a második leggyakoribb malignóma. A probléma vele, hogy tünetszegény, a rendszeres, alapos stomato-onkológiai szürés során is szinte észrevehetetlen, leggyakrabban előrehaladott állapotban, vagy véletlen mellékleletként kerül diagnosztizálásra. Kezelését tekintve az immunkemoterápiás kezelés az első választandó, azonban ennek sikeraránya mérsékelt [10].

A fenti páciens esete is rámutat arra az íratlan szabályra, hogy a „páciensnek mindig igaza van”. Nevezetesen a korrekt diagnózishoz fokozott figyelemmel kell lenni a páciens panaszait, anamnézisét illetően. $A$ bemutatott páciens esetében a még éppen időben történt diagnózis és a mielőbbi adekvát kezelés szerencsés kimenetelt eredményezett, az eddig eltelt 20 hónap alatt recidívát nem észleltünk.
A fogászati kezelés menetét nagymértékben befolyásolják az esetleges alapbetegségek, ahogy azt az esetbemutatóban is ismertettük, azonban ez nem jelentheti a fogászati kezelés kontraindikációját, bizonyos esetekben kompromisszumokra kényszerülünk, ekkor az optimális kockázat/haszon arányt kell szem előtt tartani [14].

A mai világban, amikor az implantációs protetika térhódítása egyre dinamikusabban halad előre, a teljes és részleges lemezes fogpótlások megítélése a pácienseknél egyre negatívabb, amiben a nem mindig korrekt marketingnek is szerepe van. Azonban egy megfelelő gondossággal elkészített kivehető fogpótlás megfelelő alternatíva lehet a foghiánnyal rendelkező páciensek protetikai ellátásakor, a megfelelő indikáció esetén.

A közlemény megírása anyagi támogatásban nem részesült. Szerzői munkamegosztás: M. K.: Páciens felvétele, diagnosztikája, ellátása, cikk megírása. F. P.: Haematológiai ellátás, S. P.: Gnatológiai munkafázisok ellenőrzése, K. K.: Kezelési terv készítése, kezelés menetének ellenőrzése. A szerzők kijelentik, hogy a cikk végleges változatát valamennyien elolvasták, azt jóváhagyták.

\section{Irodalom}

1. Adwani D, Arora R, Bhattacharya A, Bhagat B: Non-Hodgkin's lymphoma of maxillary sinus: An unusual presentation. Annals of Maxillofacial Surgery 2013; 3: 95-97. https://doi.org/10.4103/2231-0746.110079

2. Brody A, Zalatnal A, Csomo K, Belik A, Dobo-Nagy C: Difficulties in the diagnosis of periapical translucencies and in the classification of cemento-osseous dysplasia.

BMC Oral Health 2019; 19: 1-8. https://doi.org/10.1186/s12903-019-0843-0

3. de Castro MS, Ribeiro CM, de Carli ML, Pereira aAC, Sperandio FF, de Almeida OP, et al: Fatal primary diffuse large B-cell lymphoma of the maxillary sinus initially treated as an infectious disease in an elderly patient: A clinicopathologic report. Gerodontology 2018; 35: 59-62. https://doi.org/10.1111/ger.12308

4. KreISEL FH: Hematolymphoid Lesions of the Sinonasal Tract. Head Neck Pathol 2016; 10: 109-117. https://doi.org/10.1007/s12105-016-0698-5

5. Mensch K, Nagy G, Nagy A, Brody A: [Characteristics, diagnosis and treatment of the most common bacterial diseases of the oral cavity]. Orv Hetil 2019; 160: 739-746. https://doi.org/10.1556/650.2019.31377

6. Mensch K, Pongracz J, Nagy A, Kristof K, Bechir A, Pacurar M, et al: Preventive and Therapeutic Effects of Chlorhexidine Containing Varnish on Candida Biofilm. Revista De Chimie 2017; 68: 2808-2811. https://doi.org/10.37358/RC.17.12.5983

7. Mensch K, Szarka K, Mensch H, Dobal A, Magyar Z, Pacurar M, et al: PCR Technique Assisting the Early Diagnosis of Human Papillomavirus A retrospective clinical study. Revista De Chimie 2018; 69: 2781-2787. https://doi.org/10.37358/RC.18.10.6624

8. NAGY Z, Schmidt $P$, HeRmann P: Egyéni rágópályák kialakításának jelentősége temporomandibuláris ízületi diszfunkció esetén. Esetismertetés. Fogorvosi Szemle 2012; 105: 167-171.

9. Nagy Z, Schmidt P, Hermann P: Temporomandibuláris ízületi panaszokkal rendelkező páciens okklúziójának teljes rehabilitációja. Esetismertetés. Fogorvosi Szemle 2013; 106: 7-10. 
10. Nguyen L, Papenhausen $P$, Shao H: The Role of c-MYC in B-Cell Lymphomas: Diagnostic and Molecular Aspects. Genes (Basel) 2017; 8: 1-23. https://doi.org/10.3390/genes8040116

11. Sharma A, Rahul GR, Poduval St, Shetty K: Assessment of Various Factors for Feasibility of Fixed Cantilever Bridge: A Review Study. ISRN Dentistry 2012; 2012: 1-7. https://doi.org/10.5402/2012/259891
12. Simonffy L, Gyulai-GaÁl S, Dobo-Nagy C, Szabo BT: Fibrosus dysplasia differenciál-diagnózisa. Fogorvosi Szemle 2018; 111: 74-78.

13. Somfai D, Zsigmond Á, Károlyházy K, Kispélyı B, Hermann P: Cirkónium-dioxid használata a klinikai gyakorlatban. Fogorvosi Szemle 2015; 121-125.

14. VAN WAAS MA: [Indications for removable partial dentures]. Ned Tijdschr Tandheelkd. 2009; 116: 593-596.

Mensch K, Schmidt P, Farkas P, Károlyházy K

\section{Life-saving early diagnosis in the dental chair: Diffuse large B-cell lymphoma in the maxillary sinus}

Case report and literature review

Non-Hodgkin's lymphomas are rare forms of the head and neck malignancies. It is often accidentally diagnosed or in an advanced phase by the onset of clinical symptoms. It is possible to diagnose it during stomato-oncological screening if it is to spread towards the oral cavity. This paper presents the diagnostic steps, oncological care, and complete dental rehabilitation of a patient, with diffuse large B-cell lymphoma localised in the maxillary sinus. The course of the treatment was mainly determined by the patient's underlying disease. At the end thanks to the early diagnosis and the successful oncological treatment, started on time, the tumour showed complete remission and after eighteen months, no relapse occurred. The patient's general condition is good, he is satisfied with the completed dental restorations and dental works and he is regularly monitored by his doctors.

Keywords: Non-Hodgkin lymphoma, sinus maxillaris, stomato-oncological screening, prosthodontics 